American Journal of Agricultural and Biological Sciences 6 (2): 185-188, 2011

ISSN 1557-4989

(C) 2011 Science Publications

\title{
Trichoderma sp Native from Chili Region of Poanas, Durango, Mexico Antagonist against Phytopathogen Fungi
}

\author{
Gabriela Barragan Valencia, Vicente Hernandez Vargas, Jose Natividad Uribe Soto, \\ Nestor Naranjo Jimenez and Jesus Herrera Corral \\ Interdisciplinary Research Centre for Integral Regional Development-Durango, \\ National Polytechnique Institute (CIIDIR-Dgo.-IPN). Project SIP: 20100421, \\ Sigma 119, Fracc.: 20 de Noviembre II, Durango, Dgo., 34220, Mexico
}

\begin{abstract}
Problem statement: Presence of Trichoderma spp. in agricultural soils decrease incidence of diseases by phytopathogen fungi. Sanity diagnostic require to know if exist beneficial microorganism and what agricultural practices help to their propagation. Approach: Samples (30) were taken from soils and sick plants of ten sites in four localities of Valley of Poanas. Phytophthora capsici Leo, Rhizoctonia solani Kühn and Trichoderma sp were isolated in agar V8 and were identified by microscopy. Results: In the 30 samples analyzed the presence of Phytophthora capsici Leo and Rhizoctonia solani Kühn was determined. Two isolations of Trichoderma sp were obtained from soil, they had antagonist activity against to $P$. capsici and $R$. solani on agar-V8 medium and showed chitinase activity. Sugar production in chitinase $\left(10 \mathrm{mg} \cdot \mathrm{mL}^{-1}\right)$ by crude extract of Trichoderma growth in basal medium more chitin was determined. The average of sugar production from strains were 0.1175 and $0.1125 \mathrm{mg} \cdot \mathrm{mL}^{-1}$ and standard deviations were 0.0567 and 0.0567 in four repetition. Interviews were applied to fifty farmers about cultivars and cultivation practices. At least seven types of chili were cultivated in the region of the Valley of Poanas, inorganic fertilization, irrigation systems by channel, gates and pumps were used. One hundred percent of farmers reported diseases of Damping off and Phytophthora root. Biocides were not used to control these diseases. Conclusion: The natural presence of Trichoderma spp was detected in Valley of Poanas, but some practices as inorganic fertilization and irrigation system can be contributing to propagation of phytopathogen fungi.
\end{abstract}

Key words: Damping off, Phytophthora root rot, chitinase activity, phytopathogen fungi, Trichoderma spp, Capsicum annuum, sick plants, antagonist microorganism, antagonist activity

\section{INTRODUCTION}

Mexico is the second producer of chili in the world and the state of Durango occupied the fifth place at national level. Cultivation of chilis (Capsicum annuum) in Valley of Poanas, Durango, Mexico is an important activity, generating an average of 158 wages per hectare. In the Valley 5, 000 ha are cultivated, contributing $75 \%$ of the production and surface dedicated to chili in Durango (SAGARPA, 2010). The Valley of Poanas is localized in the southeast of the state of Durango and is formed by mountain chain and plains belonging to Western Chain Mountain Mother ("Sierra Madre Occidental") at municipalities Súchil, Vicente Guerrero, Nombre de Dios and Poanas, Dgo. The chili is the main vegetable cultivated in the region. This crop suffers different kinds of problem as hail, floods and attack of phytopathogen. Damping off, stem and foliar blight, Phytophthora root rot, are pathologies caused by fungi as Phytophthora capsici Leo, Fusarium spp., Rhizoctonia solani Kühn., Alternata spp. and are factors limiting yield (Fayzalla et al., 2009; Bnejdi et al., 2010). One method to control the phytopathogen fungi is by antagonist microorganisms as Trichoderma spp. That is possible due to species of Trichoderma have lytic activity against to phytopathogen, compete for substrates, synthesize antibiotics and confer resistance to plants against phytopathogen fungi (Schuster and Schmoll, 2010), besides offer the advantages of: does not pollute, can be used with chemical fungicides and cupper (Schuster and Schmoll, 2010). There are commercial products of Trichoderma, although species of this genus are distributed in agricultural soils. The objectives of this research were

Corresponding Author: Gabriela Barragan Valencia, Interdisciplinary Research Centre for Integral Regional Development-Durango, National Polytechnique Institute (CIIDIR-Dgo.-IPN). Project SIP: 20100421, Sigma 119,

Fracc.: 20 de Noviembre II, Durango, Dgo., 34220, Mexico Tel/Fax: (52 618) 8142091 
(1) know if there is the natural presence of Trichoderma spp. in crops affected by damping-off and Phytophthora root rot and (2) obtain native strains of Trichoderma spp. and identify them.

\section{MATERIALS AND METHODS}

Ten samples of soil, 10 of root and 10 of stem were taken from the region of the Valley of Poanas, Dgo during febrero to July of 2010. Ten sites were established in four localities of the Valley for sampling. In the Table 1 are described names of the cultivar, phase of the cultivar (seedbed, flowering and fructification), locality and coordinates. The places were selected randomly with a condition to have problem of damping-off and Phytophthora root rot.

Agar-V8 mediums were inoculated with samples of root, stem plant and soil. The petri dishes were incubated at $37^{\circ} \mathrm{C}$ during 24, 48 and $72 \mathrm{~h}$. Trichoderma $\mathrm{sp}$ and phytopathogen fungi strains were isolated of the mediums and transfered to fresh medium. Mycelium of the isolates were visualized by microscopy and photographies were taken. Tests of parasitism were developed. Agar-V8 mediums were inoculated with Phytophthora and Trichoderma at the same time. Two types of assays were evaluated: (1) inoculum of each one in the extreme of the dish and (2) inoculum of each one in the middle of the dish in the same place. The inocula were obtained from one $\mathrm{cm}$ of the radio of center of the dish and their sizes were of $0.5 \mathrm{~cm}^{2}$. The dishes were incubated at $37^{\circ} \mathrm{C}$ during 24,48 and $72 \mathrm{~h}$. Photographies were taken of the myceliums obtained. Tests of chitinase activity were developed according to (Gonzalez et al., 2010); isolated strains of Trichoderma were cultivated in basal medium with chitin $(5 \mathrm{mg}$. $\mathrm{mL}^{-1}$ ) during $48 \mathrm{~h}$. Crude extracts of $500 \mu \mathrm{L}$ were transfered to new tube with $500 \mu \mathrm{L}$ of chitin $(10 \mathrm{mg}$. $\mathrm{mL}^{-1}$ ) and were incubated at $37^{\circ} \mathrm{C}$ during $3 \mathrm{~h}$. Production of sugars in crude extracts was quantified by dinitrosalicylic acid method. Interviews were done to 50 farmers about cultivar, kind of fertilization, irrigation system, pathologies observed and fungicides, insecticides applied.

\section{RESULTS}

$R$. solanni and $P$. capsici were detected in 10 samples of each following: soil, roots and stems. Pathogens were identified by microscopy (those results are not show). Damping off was observed by the loss of plants and root rot in seedbed. Phytophtora root rot by wilt of plant and fungi in root. In the plots, ever there were plants healthy at sides of sick plants.
Trichoderma sp strains were isolated from two samples of soil from two different sites one of sampling in seedbed (site 3, Table 1) and other in plot at flowering (site 9). Trichoderma strains were identified by microscopy and by morphology in medium agar-V8 according description of (Infante et al., 2009; Schuster and Schmoll, 2010). White mycelium appeared at $24 \mathrm{~h}$ of growth on agar v8 and after $48 \mathrm{~h}$ turned green. In microscopic views, it was possible watch: conidiophore were branched that finished in phialides where conidia were formed (Fig. 1).

Trichoderma sp inhibited the growth on agar v8 of $P$. capsici and $R$. solani as show in the Fig. 2. When the inoculua were placed in middle of the dish Trichoderma sp covered the most part of the dish at $72 \mathrm{~h}$ and when the inoculua of each one were placed in opposite side, at $72 \mathrm{~h}$ of growth Trichoderma began to invade the mycelium of $R$. solani. Parasitism of Trichoderma sp over $P$. capsici and $R$. solani was observed by microscopy (Fig. 3).

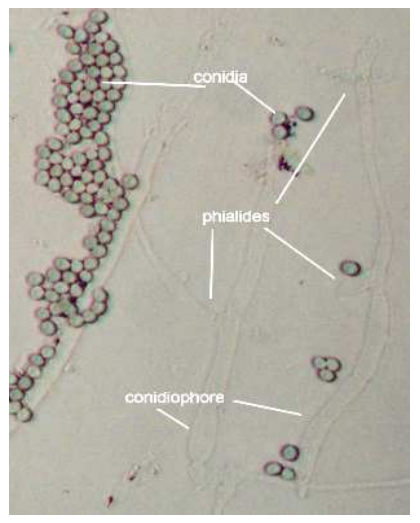

Fig. 1: Identification of Trichoderma sp by microscopic view (400x)

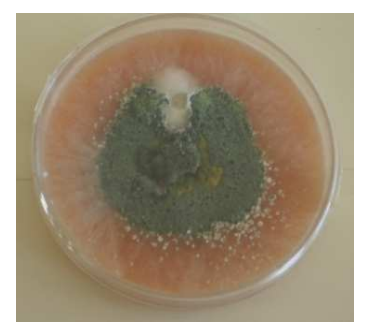

(A)

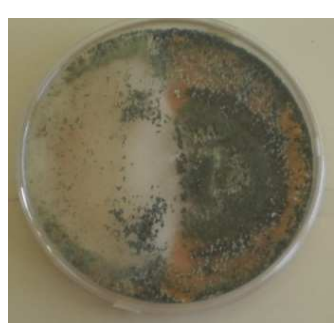

(B)
Fig. 2: Inhibition of propagation of $R$. solani by Trichoderma sp (A) R. solani and Trichoderma spp were inoculated in the center of the dish; (B) $R$. solani and Trichoderma sp were inoculated in opposite position in the dish 
Am. J. Agri. \& Biol. Sci., 6 (2): 185-188, 2011

\begin{tabular}{|c|c|c|c|c|}
\hline Site & Type of chili & Phase of cultivar & Municipality of Durango, México & Coordinates \\
\hline$\overline{1}$ & "Puya" & Seedbed & Sta. Cruz de Guadalupe & $\begin{array}{l}\text { N 23 } 51.284^{\prime} \\
\text { W } 104^{\circ} 10.624^{\prime} \\
\text { Altitude: } 6079 \mathrm{ft}\end{array}$ \\
\hline 2 & "Puya" & Seedbed & Potosi & $\begin{array}{l}\text { N } 23^{\circ} 56.832^{\prime} \\
\text { W } 104^{\circ} 06.355^{\prime} \\
\text { Altitude: } 6190 \mathrm{ft}\end{array}$ \\
\hline 3 & $\begin{array}{l}\text { Poblano } \\
\text { "Puya" } \\
\text { blond }\end{array}$ & Seedbed & Orizaba & $\begin{array}{l}\text { N } 23^{\circ} 57.348^{\prime} \\
\text { W } 104^{\circ} 03.870^{\prime} \\
\text { Altitude: } 6302 \mathrm{ft}\end{array}$ \\
\hline 4 & $\begin{array}{l}\text { "Puya" } \\
\text { Poblano }\end{array}$ & Seedbed & Orizaba & $\begin{array}{l}\text { N 23⒌ } 57.411^{\prime} \\
\text { W } 104^{\circ} 04.215^{\prime} \\
\text { Altitude: } 6315 \mathrm{ft}\end{array}$ \\
\hline 5 & "Puya" & Seedbed & Murguía & $\begin{array}{l}\mathrm{N} 23^{\circ} 48.392^{\prime} \\
\text { W } 104^{\circ} 05.656^{\prime} \\
\text { Altitude: } 6207 \mathrm{ft}\end{array}$ \\
\hline 6 & Poblano & Flowering & Orizaba & $\begin{array}{l}\mathrm{N} 23^{\circ} 57.503^{\prime} \\
\text { W } 104^{\circ} 04.010^{\prime} \\
\text { Altitude: } 6320 \mathrm{ft}\end{array}$ \\
\hline 7 & "Puya" & $\begin{array}{l}\text { Flowering } \\
\text { Fructification }\end{array}$ & Sta. Cruz de Gpe & $\begin{array}{l}\mathrm{N} 23^{\circ} 51.014^{\prime} \\
\text { W } 104^{\circ} 09.759^{\prime} \\
\text { Altitude: } 6142 \mathrm{ft}\end{array}$ \\
\hline 8 & "Puya" & $\begin{array}{l}\text { Flowering } \\
\text { Fructification }\end{array}$ & Sta. Cruz de Gpe & $\begin{array}{l}\mathrm{N} 23^{\circ} 51.575^{\prime} \\
\mathrm{W} 104^{\circ} 09.723^{\prime} \\
\text { Altitude: } 6135 \mathrm{ft}\end{array}$ \\
\hline 9 & "Puya" & $\begin{array}{l}\text { Flowering } \\
\text { Fructification }\end{array}$ & Sta. Cruz de Gpe. & $\begin{array}{l}\mathrm{N} 23^{\circ} 51.269^{\prime} \\
\text { O } 104^{\circ} 09.812^{\prime} \\
\text { Altitude: } 6112 \mathrm{ft}\end{array}$ \\
\hline 10 & $\begin{array}{l}\text { "chilaca" } \\
\text { "Jalapeño" } \\
\text { Poblano }\end{array}$ & $\begin{array}{l}\text { Flowering } \\
\text { Fructification }\end{array}$ & Potosi & $\begin{array}{l}\mathrm{N} 23^{\circ} 56.871^{\prime} \\
\text { W } 104^{\circ} 06.353^{\prime} \\
\text { Altitude: } 6208 \mathrm{ft}\end{array}$ \\
\hline
\end{tabular}

Table 2: Production of sugar from chitin by crude extract of Trichoderma sp in equal volumes

\begin{tabular}{lll}
\hline \multicolumn{3}{c}{ Trichoderma sp in equal volumes } \\
& Production of sugars $\left(\mathrm{mg}^{\mathrm{m}} \mathrm{mL}^{-1}\right)$ \\
\hline Repetition & Strain 1 (site 3) & Strain 2 (site 9) \\
\hline 1 & 0.1000 & 0.1500 \\
2 & 0.2000 & 0.0800 \\
3 & 0.0700 & 0.1700 \\
4 & 0.1000 & 0.0500 \\
Average & 0.1175 & 0.1125 \\
Standard deviation & 0.0567 & 0.0567 \\
\hline
\end{tabular}

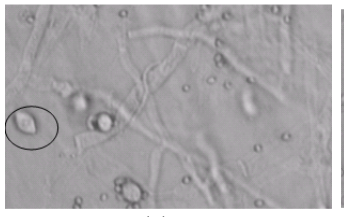

(a)

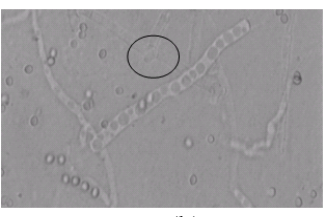

(b)
Fig. 3: Micoparasitism views. A: Hyphae coiled of Trichoderma sp on $P$. capsici. (Circle closed spore of $P$. capsici). B: Micoparasitism of Trichoderma sp on $R$. solani (Circle closed typical "T" form of $R$. solani)

Enzymatic activity was found, production of sugar was obtained from chitin $\left(10 \mathrm{mg} \cdot \mathrm{mL}^{-1}\right)$ with crude extract of Trichoderma sp. The quantities determined ranged from 0.05-0.2 mg.mL $\mathrm{mL}^{-1}$ (Table 2).
The results of the interviews showed that types of (Capsicum annuum) cultivated in The Valley of Poanas, Dgo. are: "puya or guajillo", "jalapeno", "serrano", "habanero", "guierito" "rat tail" "chilaca", blond and "ancho or Poblano" (Fig. 4).

The farmers whom cultivate Poblano chili use creole or commercial seed. The name of commercial seed is Caballero chili. All others seeds of chilis used are creole. "Puya or guajillo" is the type of chili that $90 \%$ of farmers cultivate in major volume (more that $50 \%$ of crop) and this is commercialized dried. Fertilization is inorganic, the fertilizers used are urea, diammonium phosphate and potassium chloride. The organic fertilization is not used. Compost or liquid humus are applied occasionally when someone more recommends. Irrigation systems are by hose, multigates, channel and pump. The cultivar of chili is of irrigation although on july-august-september is rain time. Waterlogging are common in plots. The pathologies described in cultivar of chili by farmers and observed in field trips were: damping off, stem and foliar blight and Phytophthora root rot. Fifty of fifty farmers reported those diseases in cultivars of chili. The products used against pest and diseases are: Ridomil ${ }^{\circledR}$, Captan $^{\circledR}, \quad$ Previcure $^{\circledR}, \quad$ Paration $^{\circledR}, \quad$ Tamaron $^{\circledR}$, MaxiGrow $^{\circledR}$, lime. Biocides are not used. 


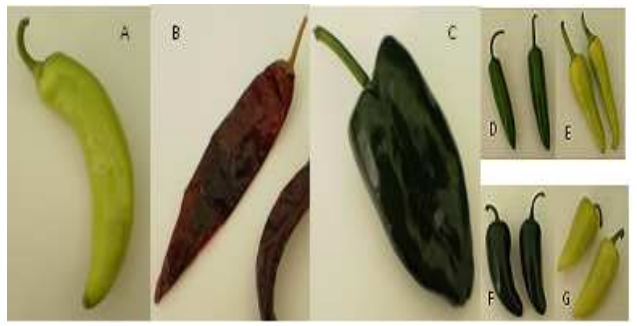

Fig. 4: Types of chilis (Capsicun annuum) cultivated in The Valley of Poanas, Dgo; (A) "chilaca"; (B) dried "puya"; (C) Poblano; (D) "serrano"; (E) "güerito" (F) "jalapeño"; (G) blond

\section{DISCUSSION}

The practices of farmers of cultivating different varieties, select seeds and rotation crops, permits to say that biodiversity of chili in the Valley of Poanas, Dgo. is preserved. The diseases of damping off and Phytophthora root rot are generalized in all chili cultivar of the region and are due to phytopathogen fungi as $R$. solani and $P$. capsici (Steiner et al., 2008; Fayzalla et al., 2009). In attention to observations that exist healthy plants at sides of affected plant, it's possible say there is natural resistance to phytopathogen. It's probably that natural presence of Trichoderma spp. in soil of plots is contributing to resistance like reported for (Ningthoujam et al., 2009; Al-Taweil et al., 2009); but some practices as entirely inorganic fertilization, irrigation systems used and waterlogging frequently are not recommend to bring down phytopathogen fungi and to increase the population of antagonist (Hayyan, 2009).

Trichoderma spp. are present in soils of Valley of Poanas, Dgo. The strains isolated have antagonist activity against $P$. capsici and $R$. solani as is mentioned for some species of Trichoderma (Argumedo et al., 2009; Schuster and Schmoll, 2010). By microscopy we could see hyphae coiled of Trichoderma sp on $P$. capsici as described (Infante et al., 2009). The isolation obtained have chitinase activity as described (Infante $e t$ al., 2009; Gonzalez et al., 2010). However, the problem of Damping off and Phytophthora root rot is generalized in plots. Addition of inorganic fertilizers, no disinfection of seed and use of insecticides can be affecting the presence of Trichoderma spp. in soils and favor the propagation of phytopathogen fungi (AlTaweil et al., 2009).

\section{CONCLUSION}

The natural presence of Trichoderma spp was detected in Valley of Poanas, but some practices as inorganic fertilization entirely and irrigation systems can be contributing to propagation of phytopathogen fungi. It's necessary to reconsider use of compost and liquid humus, developing different irrigation systems as drip and implement disinfection of seed in order to stimulate the propagation of Trichoderma spp., decrease the level of phytopathogen fungi and improving the system production of chili in Poanas, Dgo.

\section{REFERENCES}

Argumedo, D.R., A. Alarcón, C.R. Ferrera and C.J.J. Pena, 2009. The fungal genus Trichoderma and its relationship with organic and inorganic contaminants. Int. J. Ambiental Pollut., 25: 257-269 Http:/ www.atmosfera.unam.mx/editorial/rica/acervo/vol_ 25_4/6.pdf

Bnejdi, F., M. Saadoun, A.M. Bechir, C. Hanbury and G.M. El, 2010. Relationship between epistasis and aggressiveness in resistance of pepper (Capsicum annuum L.) to Phytophthora nicotianae. Genetics Molecular Biology Online. http:/www.scielo.br/pdf/gmb/2010nahead/2009147.pdf

Ningthoujam, D.S., S. Sanasam and S. Nimaichand, 2009. Screening of actinomycete isolates from niche habitats in Manipur for antibiotic activity. Am. J. Biochem. Biotechnol., 5: 221-225. DOI: 10.3844/ajbbsp.2009.221.225

Fayzalla, E.A., E. El-Barougy and M.M. El-Rayes, 2009. Control of soil-borne pathogenic fungi of soybean by biofumigation with mustard seed meal. J. Applied Sci., 5: 2272-2279.

Gonzalez, I., D. Infante, B. Peteira, B. Martinez and Y. Arias et al., 2010. Biochemical characterization of isolates of Trichoderma spp. promising biological control agent. J. Vegetal Protection, 25: 58-63. http://www.censa.edu.cu/index2.php?option $=$ com docman\&task=doc_view\&gid=854\&Itemid $=105$

Al-Taweil, H.I., M.B. Osman, A.H. Aidil and W.M.W. Yussof, 2009. Optimizing of Trichoderma viride cultivation in submerged state fermentation. Am. J. Applied Sci., 6: 1284-1288. DOI: 10.3844/ajassp.2009.1284.1288

Infante, D., B. Martinez, N. Gonzalez and Y. Reyes, 2009. Mechanisms of action of Trichoderma against fungal pathogens. J. Vegetal Protection. 24: 14-21. www.censa.edu.cu/index2.php?option=com_docman

SAGARPA, 2010. Agricultural Statistical Yearbook. www.sagdr.gob.mx

Schuster, A.M. and Schmoll, 2010. Biology and biotechnology of Trichoderma. Applied Microbiol. Biotechnol. DOI: 10.1007/500253-010-2632-1

Steiner, O., R. Sy and P.W. Bosland, 2008. Recombinant inbred line differential identifies race-specific resistance to Phytophthora root rot in Capsicum annuum. Phytopathology, 98: 867-870. DOI: 10.1094/PHYTO-98-8-0867 